ISSN: 1410-8917

Jurnal Kimia -Sains \& Aplikasi

e-ISSN: 2597-9914

\section{Jurnal Kimia Sains dan Aplikasi Journal of Scientific and Applied Chemistry}

Journal homepage: http://ejournal.undip.ac.id/index.php/ksa

\title{
Review: Potensi mikrobial selulase, xilanase, dan protease dalam fermentasi kopi luwak (Paradoxurus hermaphroditus) secara in vitro
}

\author{
Warsono El Kiyat ${ }^{\mathrm{a}, 1}$, Dessy Mentari ${ }^{\mathrm{b}, 2}$, Natalia Santoso ${ }^{\mathrm{b}, 3}$ \\ a Department of Food Technology, Faculty of Engineering, Bina Nusantara University, Jakarta, Indonesia \\ ${ }^{\mathrm{b}}$ Department of Nutrition \& Food Technology, Faculty of Life Sciences, Surya University, Banten 15117, Indonesia \\ Author email: ${ }^{1}$ warsono.el.kiyat@gmail.com; ${ }^{2}$ desdessymentari@gmail.com; ${ }^{3}$ natalia.santoso14@student.surya.ac.id
}

https://doi.org/10.14710/jksa.22.2.58-66

\section{Article Info}

Article history:

Received: 6 December 2018

Revised: 21 March 2019

Accepted: 22 March 2019

Online: 31 March 2019

\section{Keywords:}

cellulase; civet coffee; in vitro fermentation; protease; xylanase

\section{Abstract}

Title: Review: Potential of Microbial cellulase, xylanase, and protease on in vitro fermentation of civet (Paradoxurus hermaphroditus) coffee

Civet coffee is a highly priced coffee with distinctive aromas and flavours that produced from partially fermented coffee beans in the digestive system of the civet (Paradoxurus hermaprodithus). The high demand of this coffee and its unique natural production have implications for the animal welfare and controversy of halal status of the product. In vitro fermentation using cellulase, xylanase, and protease that isolated from civet faeces seems to be an alternative process $s$ to resolved animal-abuse issue, halal status of the product as well as to ensure sustainability of civet coffee production. This paper was aimed to summarize and synthesize the roles of these three enzymes (cellulase, xylanase, and protease) in in vitro fermentation of civet coffee and their effects on chemical and sensory characteristics based on the most recent research studies. Results showed that in vitro fermentation using cellulase, xylanase and protease of coffee beans resulted in similar chemical and sensory characteristics as those produced through natural process that involved civet animals.

\section{Abstrak}

Kopi luwak adalah kopi bernilai tinggi dengan aroma dan rasa khas, yang dihasilkan dari biji kopi yang telah difermentasi sebagian dalam sistem pencernaan luwak (Paradoxurus hermaprodithus). Tingginya permintaan kopi ini dan produksi alami yang unik berimplikasi pada praktek pemaksaan dan penyiksaan hewan luwak, serta adanya kontroversi status kehalalan produk. Fermentasi in vitro menggunakan selulase, xilanase, dan protease yang diisolasi dari kotoran luwak tampaknya dapat menjadi alternatif proses untuk menghindari masalah pelecehan hewan, menjamin kehalalan produk serta memastikan keberlanjutan produksi kopi luwak. Kajian ini bertujuan untuk meringkas dan mensintesis peran tiga enzim ini (selulase, xilanase, dan protease) dalam fermentasi in vitro kopi luwak dan pengaruhnya pada karakteristik kimia dan sensori berdasarkan hasil-hasil penelitian terbaru. Hasil kajian menunjukkan bahwa fermentasi in vitro menggunakan selulase, xilanase, dan protease. biji kopi menghasilkan karakteristik kimia dan sensorik yang sama dengan yang dihasilkan melalui proses alami yang melibatkan hewan luwak. 


\section{Pendahuluan}

Kopi luwak adalah kopi yang diproses melalui fermentasi singkat yang terjadi di dalam saluran pencernaan luwak (Paradoxurus hermaphroditus) [1, 2, 3]. Enzim-enzim pada saluran pencernaan tersebut berperan dalam menghasilkan kopi dengan cita rasa dan aroma khas [4]. Kopi luwak merupakan salah satu jenis kopi yang paling banyak diminati di dunia [5]. Adanya ciri khas unik yang dimiliki oleh kopi luwak ini menjadikan kopi luwak memiliki harga yang cukup tinggi [6] dan salah satu yang paling mahal di dunia dengan harga sekitar \$1.300/kilogram [2].

Saat ini, kebutuhan kopi luwak 100\% masih tergantung secara alami [7], yaitu hanya berasal dari hasil fermentasi oleh luwak. Penggunaan hewan pada proses produksi kopi luwak memiliki beberapa permasalahan, seperti: penyalahgunaan hewan yang berpotensi pada animal abuse [8], produktivitas hewan yang sangat terbatas karena tidak mudah untuk dikembangbiakkan [8] dapat memicu kerusakan ekosistem hewan yang berimplikasi pada kelangkaan dan kepunahan luwak di kemudian hari [9]. Selain itu, karena prosesnya yang melibatkan saluran pencernaan hewan, status kehalalan dari kopi luwak juga masih diperdebatkan [10, 11], meskipun Majelis Ulama Indonesia (MUI) telah memberikan fatwa halal, dengan syarat biji kopi luwak disucikan sebelum dikonsumsi [12]. Begitu juga dengan keotentikannya, masih banyak terjadi pemalsuan kopi luwak yang dicampur dengan jenis kopi lain yang lebih murah [13], meskipun beberapa penelitian telah menemukan metode terkini untuk mendeteksi keaslian kopi luwak [14, 15, 16, 17].

Untuk mengurangi penggunaan hewan luwak pada pembuatan kopi luwak, dapat dilakukan melalui proses fermentasi secara in vitro, baik menggunakan mikroorganisme $[7,13,18,19]$ maupun enzim $[18,20]$. Mikroorganisme dan enzim diyakini dapat menghasilkan kopi yang terfermentasi menjadi lebih unik dengan cita rasa dan aroma yang khas [1]. Penggunaan mikroorganisme dan enzim ini diharapkan dapat mengatasi permasalahan yang terjadi dalam penggunaan hewan luwak, seperti biaya produksi yang mahal [21], kemungkinan kontaminasi yang tinggi dari $E$. coli dan Salmonella [22], dan produksinya yang terbatas [13]. Mikroorganisme yang digunakan dalam fermentasi kopi luwak secara in vitro pada umumnya merupakan kelompok bakteri yang berasosiasi dengan saluran pencernaan luwak [23]. Bakteri-bakteri tersebut antara lain diisolasi dari sampel feses [19, 24] atau dari bagian gastrointestinal luwak [28]. Beberapa bakteri yang ditemukan pada usus luwak, di antaranya: Enterobacter cloacae, Lactobacillus brevis, Enterobacter, Bacillus dan beberapa bakteri lain dalam jumlah yang lebih sedikit [25]. Sementara itu, beberapa bakteri yang berhasil diisolasi dari feses luwak yaitu: bakteri selulolitik, xilanolitik, dan proteolitik yang terdapat dalam jumlah yang besar [26]. Bagaimanapun juga, yang bekerja dalam fermentasi kopi luwak adalah enzim, karena melalui aktivitas enzimnya, mikroorganisme dapat menghidrolisis substrat kopi luwak tersebut.

Bakteri selulolitik, xilanolitik, dan proteolitik memiliki karakteristik yang berbeda, karena enzim yang dihasilkan untuk menguraikan substrat juga berbeda. Bakteri selulolitik dapat menghasilkan selulase untuk mendegradasi selulosa, bakteri xilanolitik memproduksi enzim xilanase untuk mendegradasi xilan, sementara bakteri proteolitik dapat mensekresi protease untuk mendegradasi protein [26]. Ketiga enzim ini berperan dalam proses fermentasi kopi di dalam tubuh luwak [27] dan berpotensi untuk digunakan sebagai agen enzimatis dalam fermentasi kopi luwak secara in vitro. Seperti yang telah dilakukan Hadipernata dan Nugraha yang menggunakan protease menggunakan bioreactor [13]. Hal ini juga dilakukan oleh Zahiroh [28] dan Rohman [29] yang menggunakan selulase, xilanase, dan protease dengan memanfaatkan bakteri yang telah diisolasi. Xilanase merupakan enzim yang dapat menghidrolisis hemiselulosa (xilan atau polimer dari xilosa) dan xilooligosakarida [30]. Protease merupakan enzim yang mampu mengkatalisis reaksi hidrolisis ikatan peptida pada [31] yang terdapat pada protein di dalam kopi, sementara selulase merupakan enzim yang mampu memutus ikatan $\beta-1,4$ pada substrat selulosa, selodekstrin, selobiosa dan turunan selulosa lainnya [32].

Adapun tujuan dari kajian ini yaitu untuk menganalisis bagaimana kerja mikrobial selulase, xilanase, dan protease dalam memfermentasi kopi secara in vitro. Selain itu, dari kajian dapat dianalisis peran fermentasi secara in vitro dalam memberikan karakteristik kimia dan sensori dari kopi luwak. Melalui kajian ini, diharapkan dapat diketahui bagaimana fermentasi kopi luwak secara in vitro dapat digunakan sebagai alternatif fermentasi tradisional biji kopi pada saluran pencernaan luwak yang memiliki banyak keterbatasan.

\section{Kopi Luwak}

Kopi luwak adalah salah satu produk kopi khas Indonesia yang dihasilkan dari feses hewan luwak (Paradoxurus hermaphroditus), setelah hewan tersebut mengkonsumsi buah kopi matang [18]. Kopi yang dimakan oleh luwak kemudian keluar bersama kotorannya berupa biji kopi dengan syarat biji kopi masih utuh terbungkus kulit tanduk dan dapat tumbuh jika ditanam kembali [33]. Protease yang dihasilkan di dalam saluran pencernaan luwak memecah protein pada biji kopi, sehingga menyebabkan kandungan peptida dan asam amino bebas meningkat dan menghasilkan rasa dan aroma yang unik. Selain itu, selama fermentasi berlangsung, kadar lemak kopi meningkat dan membuat rasa kopi semakin enak dan berperan dalam pembentukan body kopi [6]. Adanya kandungan lemak yang tinggi merupakan salah satu penyebab peningkatan kualitas cita rasa kopi luwak dibandingkan kopi biasa [1, 34]. Senyawa lemak dan turunannya, yaitu: trigeliserida, asam lemak bebas, ester diterpen, diterpen bebas, triterpen, sterol, tokoferol, dan fosfatida, berperan terhadap cita rasa kopi yang dihasilkan [4]. Pada saat fermentasi, bakteri mengaktifkan beberapa enzim, seperti lipase [35] yang mengkatalis proses konversi lemak dan asam lemak bebas menjadi asam butirat [36]. Tingginya asam butirat yang dihasilkan mempengaruhi kualitas sensori kopi yang dihasilkan [29]. Rasa dan aroma yang khas ini membuat kopi menjadi banyak diminati. Diketahui bahwa harga kopi luwak cukup mahal [1], yaitu 20 kali lebih mahal dibandingkan kopi biasa [13]. Adapun perbandingkan harga kopi luwak dengan kopi lain disajikan pada Tabel 1. Berdasarkan Tabel 1 tersebut, kopi luwak menempati posisi ke-4 dari kopi 10 termahal di dunia. 
Tabel 1. Perbandingan 10 harga kopi termahal di dunia

\begin{tabular}{|c|c|c|}
\hline Jeni Kopi & $\begin{array}{c}\text { Harga per } \\
\text { pound* (dalam } \\
\text { dolar) }\end{array}$ & Daerah Asal \\
\hline Black Ivory & Lebih dari 500 & Thailand \\
\hline Finca El Injerto & 500 & Guatemala \\
\hline $\begin{array}{l}\text { Hacienda La } \\
\text { Esmeralda }\end{array}$ & Lebih dari 500 & Panama \\
\hline Kopi Luwak & 160 & Asia \\
\hline Saint Helena & 79 & Pulau St. Helena \\
\hline $\begin{array}{c}\text { Jamaican Blue } \\
\text { Mountain }\end{array}$ & Lebih dari 50 & Jamaika \\
\hline $\begin{array}{l}\text { Fazenda Santa } \\
\text { Ines }\end{array}$ & 50 & Brasilia \\
\hline $\begin{array}{c}\text { Starcbucks } \\
\text { Quadriginoctuple }\end{array}$ & 47,30/cangkir & $\begin{array}{c}\text { Philadeplhia, } \\
\text { USA }\end{array}$ \\
\hline Los Planes & 40 & El Slvador \\
\hline Hawaiiaan Kona & 34 & Hawai, USA \\
\hline
\end{tabular}

Standar mutu kopi luwak sendiri di Indonesia sampai saat ini masih mengacu pada Standar Nasional Indonesia (SNI) untuk Kopi, yaitu SNI 01-2907-2008 [33, 37]. Perbedaan kopi luwak dengan kopi biasa tidak hanya terletak pada prosesnya saja, komposisi kimia dari keduanya pun cukup berbeda (Tabel 2).

Tabel 2. Perbandingan kandungan kimia pada kopi luwak dan kopi biasa

\begin{tabular}{ccc}
\hline Kandungan Kimia & \multicolumn{2}{c}{ Konsentrasi (g/100g) } \\
\cline { 2 - 3 } & Kopi biasa & Kopi luwak \\
\hline Kafein & $1,1-2,5^{*}$ & $0,358-0,363^{* *}$ \\
Asam klorogenat & $1,9-3,8^{*}$ & $0,0544-0,0571^{* *}$ \\
Protein & $6,5-10^{*}$ & $1,09-1,11^{* *}$ \\
Polisakarida & $31-37^{*}$ & $69,16 \pm 69,72^{* * *}$ \\
Lemak & 17,37 & $19,76^{* * * *}$ \\
\hline Sumber: $*[38], * *[13], * * *[2], * * * *[34]$
\end{tabular}

Pada Tabel 2, terlihat bahwa kadar kafein pada kopi luwak lebih rendah dibandingkan kopi biasa. Hal ini disebabkan oleh adanya penurunan kandungan kafein yang terjadi selama fermentasi kopi di dalam saluran pencernaan luwak [39]. Semakin lama proses fermentasi terjadi, maka kandungan kafein pada kopi semakin sedikit, karena kafein terdegradasi menjadi uric acid, 7methilxanthine, dan xanthine [40]. Selain itu, kafein berubah menjadi kafeol yang berimplikasi pada aroma dan flavor kopi. Senyawa kafein ini juga berkontribusi terhadap rasa pahit pada kopi. Penurunan kadar kafein juga dipengaruhi oleh penguraian protein selama fermentasi. Adanya aktivitas protease yang tinggi dari bakteri proteolitik yang terdapat pada saluran pencernaan luwak, menyebabkan berkurangnya kadar kafein pada kopi serta akan meningkatkan asam amino bebas [1]. Semakin panjang proses fermentasi berlangsung, maka kadar kafein dalam biji kopi akan semakin menurun [41]. Begitu juga kadar protein pada kopi luwak, yang cenderung lebih rendah dibandingkan kopi biasa (Tabel 2).
Asam klorogenat yang terkandung di dalam kopi luwak lebih sedikit dibandingkan kopi biasa. Asam klorogenat adalah turunan dari senyawa fenol dan merupakan faktor penentu kualitas kopi khususnya aroma kopi [42]. Senyawa ini juga menentukan karakteristik pahit pada kopi [43]. Hal ini yang menyebabkan rasa kopi biasa lebih pahit dibandingkan kopi luwak [17]. Selama fermentasi berlangsung, asam klorogenat dihidrolisi oleh klorogenat hidrolase menjadi asam kafeat dan asam ferulik yang menyebabkan rasa pahit pada kopi menurun [44].

\section{Peran Selulase pada Fermentasi Kopi Luwak}

Selulosa merupakan serat utama pada dinding sel biji kopi [45]. Selulosa bersama polisakarida lain seperti arabinogalaktan dan galaktomanan sebagai fraksi karbohidrat dalam biji kopi, berkontribusi hampir 50\% dari berat kering biji kopi [46]. Selulosa ditemukan pada dinding sel tanaman, khususnya dari substrat lignoselulosa [47]. Struktur kimia selulosa terdiri dari polimer tunggal yang tersusun oleh monomer-monomer glukosa yang dihubungkan dengan ikatan glikosidik $\beta$ $1,4[48,49,50]$, yang memiliki area kristalin yang sangat teratur dan beberapa area amorphous pada interval yang tidak teratur [51]. Keteraturan struktur kristalin tersebut menyebabkan dinding sel biji kopi menjadi resisten terhadap serangan mikroba.

Enzim yang dapat mendegradasi selulosa yaitu selulase. Selulase merupakan enzim ekstraseluler yang terdiri dari 3 grup enzim [52], yaitu: kompleks endo- $\beta-$ 1,4-glukanase (EC 3.2.1.4), kompleks ekso- $\beta-1,4^{-}$ glukanase (EC 3.2.1.91), dan $\beta-1,4$-glukosidase atau selobiose (EC 3.2.1.21) [53]. Adapun mekanisme hidrolisis selulosa oleh selulase dapat dilihat pada Gambar 1. Selain itu, ikatan glikosidik $\beta-1,4$ pada selulosa dapat diputus oleh selulase menjadi monomer yang sederhana [28, 29, 54].

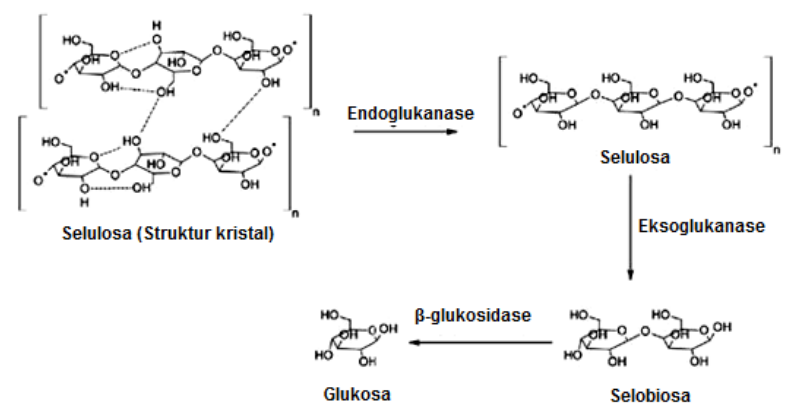

Gambar 1. Mekanisme hidrolisis selulosa oleh selulase [55]

Seperti yang ditunjukkan pada Gambar 1, hidrolisis substrat lignoselulosa terbagi menjadi dua, hidrolisis primer dan sekunder [56]. Secara umum, hidrolisis primer yang terdiri dari kerja endoglukanase dan eksoglukanase, terjadi pada permukaan substrat, mengubah rantai-rantai selulosa menjadi gula yang terlarut dengan derajat polimerisasi kurang dari enam sehingga gula yang dihasilkan umumnya berbentuk cair. Endoglukanase menghidrolisis rantai-rantai selulosa membentuk ujung-ujung rantai baru yang kemudian akan dipecah lagi menjadi selobiosa maupun selooligosakarida oleh eksoglukanase [50, 57]. Selanjutnya, hidrolisis sekunder, $\beta$-glukosidase memecah selobiosa 
menjadi glukosa. Glukosa yang dihasilkan dari fermentasi enzimatis secara in vitro ini berkontribusi dalam memberikan aroma, flavor, rasa yang lebih disukai daripada kopi pada umumnya, khususnya bagi orang yang memiliki intensitas rendah dalam meminum kopi [13]. Pada saat fermentasi, selulosa dan karbohdirat lain diubah menjadi polisakarida larut air, oligosakarida, monomer, melanoidin, senyawa karamel, dan komponen volatil. Karbohidrat berkontribusi dalam pembentukan warna cokelat pada kopi, pembentukan senyawa volatil serta meningkatkan body kopi.

Rohman [29] mengkombinasikan aktivitas selulase dengan xilanase untuk mengukur kemampuan enzim menguraikan selulosa dan hemiselulosa dalam substrat biji kopi luwak secara in vitro menjadi produk berupa glukosa dan xilosa. Aktivitas enzim diukur pada cairan hasil fermentasi yang menggunakan kombinasi isolat FLs1 (Proteus penneri) dan FLx3 (Stenotrophomonas sp. MH 34). Berdasarkan penelitian tersebut, lama inkubasi optimum dalam menghasilkan kombinasi selulase dan xilanase dari substrat biji kopi luwak secara in vitro adalah pada hari ke-3.

Isolat bakteri FLs1 dan FLx3 termasuk dalam bakteri mesofilik yang tumbuh optimal pada suhu $30^{\circ} \mathrm{C}$, sehingga enzim yang dihasilkan juga semakin banyak [29]. Kemampuan bakteri selulolitik dalam mendegradasi selulosa dan hemiselulosa pada kopi mempengaruhi kandungan asam organik dalam biji kopi [1]. Pada suhu $37^{\circ} \mathrm{C}$ (di atas suhu optimum) aktivitas enzim lebih rendah, karena pertumbuhan bakteri menjadi terhambat dan enzim yang dihasilkan lebih sedikit [54]. Bakteri yang ditumbuhkan pada kondisi lingkungan yang tidak sesuai, sulit beradaptasi dan menyebabkan pertumbuhan tidak optimal sehingga produksi enzim juga terhambat bahkan inaktif.

\section{Peran Xilanase pada Fermentasi Kopi Luwak}

Xilan merupakan polisakarida kedua yang melimpah di alam setelah selulosa dan terhitung hampir berjumlah sebanyak sepertiga dari sumber karbon organik terbarukan di bumi [58]. Struktur xilan yang bervariasi di antara spesies tanaman yang berbeda dan rantai backbone homopolimernya dapat diganti dengan gugus-gugus rantai samping berbeda pada posisi yang bervariasi pula [58]. Adapun enzim yang dapat mendegradasi xilan yaitu xilanase. Pada proses produksi kopi luwak melalui fermentasi secara in vitro, mikroorganisme seperti Stenotropomonas sp. dapat digunakan sebagai sumber xilanase [28, 29, 54]. Xilanase merupakan kompleks enzim yang terdiri dari endoxilanase (E.C.3.2.1.8), $\beta$ xilosidase (E.C.3.2.1.37), $\alpha$-glucuronidase (E.C.3.2.1.139), $\alpha$-arabinofuranosidase (E.C.3.2.1.55), dan acetilxilan esterase (E.C.3.1.1.72). Adapun mekanisme kerja xilanase dapat dilihat pada Gambar 2.

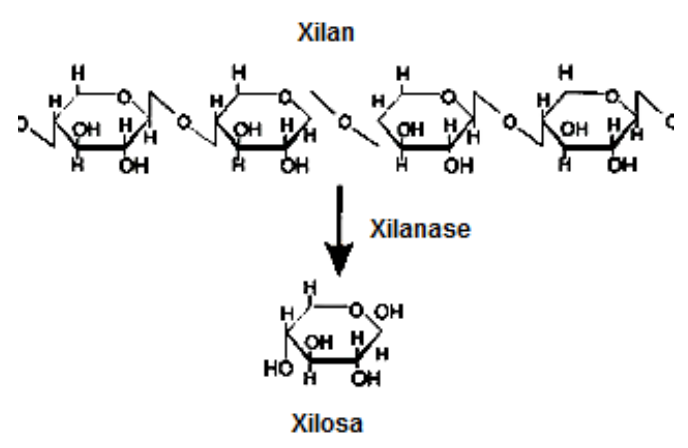

Gambar 2. Mekanisme hidrolisis xilan oleh xilanase [58]

Xilanase mendegradasi polimer xilan sebagai komponen utama dari hemiselulosa, menjadi xilosa. Xilan merupakan heteropolimer yang terutama terdiri atas gula pentosa xilosa dan arabinosa di mana backbone utama dari xilan memiliki ikatan $\beta-(1 \rightarrow 4)$ yang menghubungkan residu-residu xilosa. Xilosa diklasifikasikan sebagai monosakarida yang mengandung lima atom karbon dan termasuk gugus fungsi aldehid. Adanya gugus aldehid bebas tersebut, maka xilosa tergolong gula pereduksi. Seperti kebanyakan gula lainnya, xilosa dapat mengadopsi berbagai struktur bergantung kondisi, seperti: struktur cincin furanosa (5-member) atau piranosa (6-member) [59]. Karakteristik tersebut membantu proses ekstraksi biji kopi, khususnya dikenal sebagai coffee bean mucilage liquefraction di mana mucilage (pulp atau mesokarp) yang melapisi biji kopi (endosperma) menjadi lebih mudah terekstraksi. Dengan kata lain, biji kopi yang dihasilkan memiliki kualitas fisik yang baik, karena sudah dipisahkan dengan mucilage. Hal ini dapat memudahkan proses fermentasi kopi karena xilanase akan lebih mudah untuk mendegradasi xilan yang terdapat pada kopi [60]. Dengan hidrolisis xilan, xilosa yang dihasilkan memiliki nol kalori sehingga bisa menjadi kopi alternatif rendah kalori bagi pecinta kopi [60].

Aktivitas xilanase yang tinggi menyebabkan terjadinya degradasi selulosa, hemiselulosa, dan xilan semakin meningkat, sehingga menghasilkan produkproduk turunan seperti gula sederhana [7]. Hal ini mengakibatkan kandungan asam organik pada biji kopi semakin meningkat dan berperan dalam kualitas sensori dari kopi. Hasil dari proses pemecahan gula adalah asam laktat dan asam-asam lain yaitu etanol, asam butirat, dan propionat [13].

Xilanase berperan penting dalam fermentasi kopi luwak secara in vitro. Dengan aktivitasnya dalam mengkatalis konversi xilan menjadi gula pereduksi seperti xilosa [30], xilanase berkontribusi dalam pembentukan reaksi Maillard. Reaksi ini terjadi antara gugus aldehid yang terdapat pada gula pereduksi dengan gugus amina yang ada pada peptida sederhana, yang menghasilkan warna coklat pada biji kopi serta komponen volatil yang berimplikasi pada terbentuknya aroma dan flavor khas kopi [13].

\section{Peran Protease pada Fermentasi Kopi Luwak}

Protease atau biasa disebut proteinase, peptidase, enzim proteolitik, hidrolase protein merupakan enzim yang mampu melakukan proteolisis atau katabolisme protein melalui hidrolisis ikatan peptida. Enzim ini 
merupakan salah satu enzim yang berperan penting dalam industri, di mana penggunaannya mampu mencapai sekitar $60 \%$ dari total pemanfaatan enzim [61]. Adapun mekanisme hidrolisis protein oleh protease dapat dilihat pada Gambar 3.

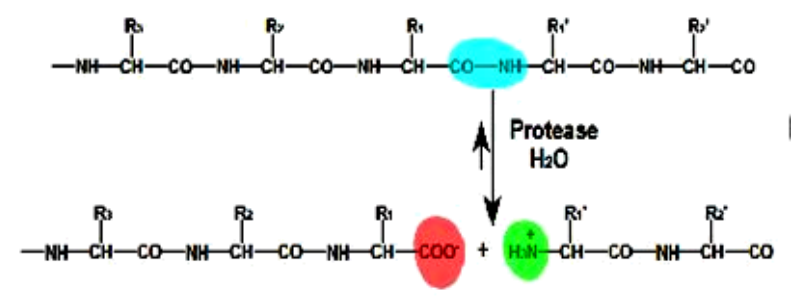

Gambar 3. Mekanisme hidrolisis protein oleh protease [62]

Sama seperti dalam pencernaan perut luwak, biji kopi diuraikan oleh salah satu enzim yaitu protease, contohnya yaitu enzim yang berasal dari Bacillus aerophillus dan Stenotropomonas sp. [28, 29, 54]. Penelitian sebelumnya menemukan bahwa hasil sekresi endogen oleh enzim proteolitik pada sistem pencernaan luwak dapat meresap ke dalam biji kopi yang melewati saluran pencernaan luwak tersebut. Enzim proteolitik memecah kandungan protein dari biji kopi sehingga asam-asam organik maupun amina seperti asam amino bebas pun meningkat dan menghasilkan aroma, rasa, dan flavor yang unik [1]. Selain itu, pada penelitian lain, yang mengisolasi bakteri asam laktat (BAL), menunjukkan bahwa dari 3 isolat yang digunakan, hanya isolat 1 (ICF 1) dan isolat 3 (ICF 3) yang memperlihatkan aktivitas protease [63]. Proses penguraian protein ini menyebabkan rasa pahit kopi luwak berkurang berbanding kopi biasa dan kopi luwak memberikan aroma tersendiri [11]. Protease secara umum digunakan untuk memecah oligopeptida menjadi asam amino [64].

Proses roasting semakin memperkuat aroma, warna, rasa dari biji kopi yang selanjutnya mengalami reaksi Mailard oleh karena biji kopi mengandung protein, asam amino, trigonelin (produk metabolisme niasin yang diekskresi dari urine luwak), serotonin, karbohidrat, asam karboksilat, fenol, dan sebagian komponen mikro lainnya. Asam-asam lemak dan turunannya yang terdapat dalam biji kopi, diantaranya: trigeliserida, ester diterpen, diterpen bebas, triterpen, sterol, tokoferol, fosfatida dan turunannya juga berperan memberikan karakteristik sensori yang lebih enak serta pembentukan konsistensi viskositas kopi setelah diseduh [4].

Masing-masing dari penelitian Rohman [29], Susilo [54], dan Zahiroh [28], meneliti aktivitas enzim dari Bacillus aerophilus sebagai isolat FLp1 dan Stenotropomonas sp $\mathrm{MH} 3$ sebagai isolat FLp2 yang berasal dari biji kopi yang ada pada feses luwak segar yang diperoleh dari perkebunan kopi. Isolat FLp1 dan FLp2 yang ditumbuhkan pada media susu skim dan didapatkan waktu optimum yang berbeda dalam memproduksi protease. Selain itu, pada penelitian yang dilakukan Hadipernata dan Nugraha yang membandingkan antara buah kopi segar, biji kopi segar dan biji kopi luwak menunjukkan bahwa enzim proteolitik hanya terdapat pada biji kopi luwak. Hal ini disebabkan oleh fermentasi yang terjadi pada biji luwak [65].

\section{Karakteristik Kimia dan Sensori Kopi Luwak Hasil Fermentasi Secara In vitro}

Melalui fermentasi secara in vitro, kopi luwak (artifisial) yang diproses menggunakan bioreaktor memiliki karakteristik kimia yang tidak jauh berbeda dengan kopi luwak yang difermentasi secara konvensional atau asli [13]. Hal ini ditunjukkan pada kadar air, abu, lemak, dan karbohidrat dari kedua kopi luwak tersebut, yang disajikan pada Tabel 3 [13]. Berdasarkan Tabel 3 tersebut, hanya kandungan protein dari kopi luwak artifisial yang lebih tinggi secara signifikan dari kopi luwak asli. Tingginya kandungan protein disebabkan oleh aktivitas bakteri asam laktat (BAL) dan enzim proteolitik yang ditambahkan ke dalam bioreakor sebelum fermentasi artifisial dilakukan [13]. Menurut Radha $d k k$. [66], protease merupakan enzim kompleks yang mengkatalisis proses hidrolisis molekul protein. Pada proses fermentasi kopi luwak asli, enzim protease ini yang menyebabkan kandungan protein menurun [4]. Dengan adanya penambahan protease pada fermentasi kopi luwak artifisial, proses degradasi protein menjadi peptida yang lebih sederhana tetap terjadi tanpa menurunkan kandungan protein secara keseluruhan jika dibandingkan dengan kopi luwak asli.

Tabel 3. Perbandingan kandungan proksimat kopi luwak artifisial dan kopi luwak asli [13]

\begin{tabular}{ccc}
\hline \multirow{2}{*}{$\begin{array}{c}\text { Kandungan } \\
\text { Kimia }\end{array}$} & \multicolumn{2}{c}{ Konsentrasi $(\mathrm{g} / 100 \mathrm{~g})$} \\
\cline { 2 - 3 } & $\begin{array}{c}\text { Kopi luwak } \\
\text { artifisial }\end{array}$ & Kopi luwak asli \\
\hline Air & $2,05 \pm 0,11$ & $2,00 \pm 0,15$ \\
Abu & $5,38 \pm 0,22$ & $5,34 \pm 0,17$ \\
Lemak & $12,21 \pm 0,19$ & $12,13 \pm 0,22$ \\
Protein & $13,11 \pm 0,23$ & $11,08 \pm 0,31^{*}$ \\
Karbohidrat & $67,25 \pm 0,33$ & $69,44 \pm 0,28$ \\
\hline
\end{tabular}

Kafein merupakan senyawa alkaloid yang terkandung secara alami pada lebih dari 60 jenis tanaman, terutama kopi. Berdasarkan penelitian yang dilakukan oleh Usman $d k k$. [7] yang melakukan fermentasi secara in vitro kopi luwak selama 12 dan 24 jam dengan penambahan mikroorganisme, menghasilkan kopi dengan kadar kafein yang tidak jauh berbeda dengan dengan kopi luwak asli. Kandungan kafein pada kopi luwak yaitu $0,7 \%$. Hal in berbeda dengan penelitian lain yang melakukan fermentasi kopi luwak menggunakan bioreaktor, di mana kadar kafein yang dihasilkan lebih rendah dibandingkan kopi luwak asli [13].

Mikroorganisme dan enzim juga diharapkan dapat menghasilkan kopi yang terfermentasi menjadi lebih unik dengan cita rasa dan aroma yang khas [1]. Oleh karena itu, karakteristik sensori yang juga berperan penting dalam menentukan kualitas kopi perlu dipertimbangkan untuk mengukur kualitas kopi luwak artifisial. Hasil penelitian sebelumnya menunjukkan bahwa fermentasi biji kopi secara basah dengan mikroorgansime probiotik yang diisolasi dari organ pencernaan luwak menghasilkan produk kopi yang memiliki cita rasa dan aroma yang mendekati kopi luwak asli. Berdasarkan cita rasa dan kenikmatannya, kopi luwak probiotik memiliki tekstur yang lebih lembut dengan cita rasa kopi yang lebih kuat daripada kopi luwak asli [21]. Produksi kopi luwak secara fermentasi dengan 
mikroba probiotik yang berhasil, setidaknya dapat menghasilkan keuntungan, di antaranya (1) produksi lebih mudah diprogramkan serta tidak terbatas, (2) biaya menjadi lebih murah, (3) bebas dari aroma tanah, (4) lebih higienis, dan (5) dapat menghilangkan perasaan jijik bagi konsumen tertentu.

Pada penelitian lain [16], yang membandingkan kualitas sensori antara kopi luwak asli dengan kopi luwak artifisial menggunakan cupping test analysis menunjukkan hasil sensori yang bervariasi dari setiap atributnya (Tabel 4), meskipun secara keseluruhan memiliki skor yang tidak jauh berbeda. Dilihat dari atribut aroma (fragrance), kopi luwak artifisial memperoleh skor yang lebih rendah dibandingkan kopi luwak asli. Hal ini disebabkan oleh kandungan protein kopi luwak artifisial yang lebih tinggi seperti yang ditunjukkan pada Tabel 3. Protein akan terdegradasi menjadi asam amino bebas yang merupakan salah satu senyawa kimia yang berkontribusi pada aroma kopi [67]. Akan tetapi, atribut after taste kopi luwak artifisal lebih rendah dibandingkan dengan kopi luwak asli. Selama proses penyangraian, terjadi reaksi Maillard antara gugus karbonil dari gula pereduksi dengan asam amino, peptida, dan protein pada kopi [68]. Reaksi ini menghasilkan senyawa melanoidin yang menyebabkan warna kopi menjadi cokelat [69] dan memberikan flavor pada kopi [70]. Jika dilihat dari atribut body kopi, skor yang dimiliki kopi luwak artifisial tidak jauh berbeda dengan kopi luwak asli. Hal ini diduga disebabkan oleh kandungan lemak yang dimiliki dari kedua kopi tersebut. Kandungan lemak yang tinggi menghasilkan body kopi yang kuat [4].

Tabel 4. Perbandingan karakteristik sensori kopi luwak artifisial dengan kopi luwak asli [13]

\begin{tabular}{ccc}
\hline Atribut sensori & $\begin{array}{c}\text { Kopi luwak } \\
\text { artifisial }\end{array}$ & $\begin{array}{c}\text { Kopi luwak } \\
\text { asli }\end{array}$ \\
\hline Aroma & 7,75 & 8,00 \\
Flavor & 7,75 & 7,75 \\
After taste & 7,75 & 7,90 \\
Keasaman & 7,63 & 7,75 \\
Body & 7,75 & 7,50 \\
Keseragaman & 10,0 & 10,0 \\
Balance & 7,88 & 8,00 \\
Keseluruhan & 7,88 & 8,00 \\
\hline
\end{tabular}

\section{Kesimpulan}

Selulase, xilanase, dan protease dapat dimanfaatkan dalam proses fermentasi kopi luwak secara in vitro. Selulase mengubah selulosa menjadi glukosa sehingga berkontribusi pada aroma, flavor, rasa kopi luwak. Kemudian, xilanase mengubah xilan menjadi xilosa yang berperan dalam produk akhir yang dihasilkan bersifat rendah kalori. Selanjutnya, protease mampu mengubah protein menjadi asam-asam organik dan amina yang juga meningkatkan karakteristik dari kopi serta konsistensi viskositas kopi setelah diseduh. Fermentasi kopi luwak secara in vitro memberikan karakteristik kimia dan sensori kopi yang tidak jauh berbeda dengan kopi luwak asli. Teknologi fermentasi tersebut dapat digunakan sebagai alternatif untuk menghasilkan kopi luwak dengan kualitas yang sama dengan kopi luwak yang difermentasi secara konvensional.

\section{Ucapan Terima Kasih}

Penulis berterima-kasih kepada Lembaga Penelitian dan Pengabdian Masyarakat (LPPM) Universitas Surya atas kesediannya untuk memberikan konsultasi dan bimbingan.

\section{Daftar Pustaka}

[1] Massimo F. Marcone, Composition and properties of Indonesian palm civet coffee (Kopi Luwak) and Ethiopian civet coffee, Food Research International, 37, 9, (2004) 901-912 https://doi.org/10.1016/j.foodres.2004.05.008

[2] Yoshikazu Nishiguchi, Michiko Goromaru-shinkai, Jun Kuroda, Sachiko Kiuchi, Hiroshi Ihara, Estimation of protein, total polyphenol, chlorogenic acid, caffeine, and caffeic acid contents in Indonesian palm civet coffee (Kopi Luwak), International Journal of Analytical Bio-Science, 5, 4, (2017) 53-56

[3] Dany Ardiansyah, Helen Tjota, Warsono El Kiyat, Review : Peran Enzim dalam Meningkatkan Kualitas Kopi, Jurnal Agri-Tek : Jurnal Penelitian Ilmu-Ilmu Eksakta, 19, 2, (2018) 86-91

[4] E. Panggabean, Buku Pintar Kopi, Agromedia Pustaka, Jakarta, 2011.

[5] Murna Muzaifa, Anshar Patria, Amhar Abubakar, Febriani, Faidha Rahmi, Dian Hasni, Ismail Sulaiman, Kopi Luwak: Produksi, Mutu dan Permasalahannya, Syiah Kuala University Press, Banda Aceh, 2016.

[6] E Panggabean, Mengeruk Untung dari Bisnis Kopi Luwak, Agromedia Pustaka, Jakarta, 2011.

[7] Doni Usman, Agung Suprihadi, Endang Kusdiyantini, Fermentasi Kopi Robusta (Coffea canephora) Menggunakan Isolat Bakteri Asam Laktat Dari Feces Luwak Dengan Perlakuan Lama Waktu Inkubasi, Jurnal Biologi, 4, 3, (2015) 31-40

[8] Udi Jumhawan, Sastia Prama Putri, Yusianto, Takeshi Bamba, Eiichiro Fukusaki, Quantification of coffee blends for authentication of Asian palm civet coffee (Kopi Luwak) via metabolomics: A proof of concept, Journal of Bioscience and Bioengineering, 122, $1, \quad$ (2016) 79-84 https://doi.org/10.1016/j.jbiosc.2015.12.008

[9] Miyabi Nakabayashi, Yoshihiro Nakashima, Andrew J. Hearn, Joanna Ross, Raymond Alfred, Hiromitsu Samejima, Azlan Mohamed, Matt Heydon, Rustam, Henry Bernard, Gono Semiadi, Gabriella Fredriksson, Ramesh Boonratana, Andrew J. Marshall, Norman T-L. Lim, Dave M. Augeri, Jason Hon, John Mathai, Tim van Berkel, Jedediah Brodie, Anthony Giordano, Jon Hall, Brent Loken, Sophie Persey, David W. Macdonald, Jerrold L. Belant, Stephanie Kramer-Schadt, Andreas Wilting, Predicted distribution of the common palm civet Paradoxurus hermaphroditus (Mammalia: Carnivora: Viverridae) on Borneo, in: The Raffles 
Bulletin of Zoology Supplement No. 33, National University of Singapore, Singapore, 2016.

[10] M. I. Mokhtar, S.M.I. Munir, Revisiting the Fiqh of halal-haram animals: An analysis on Malaysian fatwa relating to animal care and use, in: 1st International Halal Management Conference (IHMC 2017), Sejong University, South Korea, 2017.

[11] Hamizah Hussin, Mohd Anuar Ramli, Coffee Luwak Manufacturing From Halalan Tayyiban Perspectives, al-Qanatir: International Journal of Islamic Studies, 11, $1,(2018) 1-14$

[12] Majels Ulama Indonesia, Fatwa Mejalis Ulama Indonesia Nomor: 07 Tahun 2017 Tentang Kopi Luwak, in: M.U. Indonesia (Ed.) 07/2017, Majels Ulama Indonesia, Jakarta, 2017.

[13] M. Hadipernata, S. Nugraha, Process technology of luwak coffee through bioreactor utilization, IOP Conference Series: Earth and Environmental Science, 102, (2018) 012092 http://dx.doi.org/10.1088/1755$1315 / 102 / 1 / 012092$

[14] Udi Jumhawan, Sastia Prama Putri, Yusianto, Erly Marwani, Takeshi Bamba, Eiichiro Fukusaki, Selection of Discriminant Markers for Authentication of Asian Palm Civet Coffee (Kopi Luwak): A Metabolomics Approach, Journal of Agricultural and Food Chemistry, 61, 33, (2013) 79948001 http://dx.doi.org/10.1021/jf401819s

[15] Udi Jumhawan, Sastia Prama Putri, Yusianto, Takeshi Bamba, Eiichiro Fukusaki, Application of gas chromatography/flame ionization detector-based metabolite fingerprinting for authentication of Asian palm civet coffee (Kopi Luwak), Journal of Bioscience and Bioengineering, 120, 5, (2015) 555-561 https://doi.org/10.1016/j.jbiosc.2015.03.005

[16] Diding Suhandy, Meinilwita Yulia, The Use of Partial Least Square Regression and Spectral Data in UVVisible Region for Quantification of Adulteration in Indonesian Palm Civet Coffee, International Journal of $\begin{array}{llll}\text { Food Science, } & \text { 2017, } & \text { (2017) }\end{array}$ http://dx.doi.org/10.1155/2017/6274178

[17] Shinta Widyaningtyas, Sucipto Sucipto, Yusuf Hendrawan, Deteksi Pemalsuan Kopi Luwak Menggunakan Sifat Biolistrik dan Jaringan Saraf Tiruan, Jurnal Teknologi Pertanian, 19, 3, (2019) 161172

[18] Rubiyo, Juanity Towaha, Pengaruh Fermentasi terhadap Cita rasa Kopi Luwak Probiotik, Buletin Riset Tanaman Rempah dan Aneka Tanaman Industri, 4, 2 , (2013) 175-182

[19] Muhammad Fauzi, Nur Wahyu Hidayati, Perubahan Karakteristik Kimia Kopi Luwak Robusta In vitro dengan Variasi Lama Fermentasi dan Dosis Ragi, in: Seminar Nasional Hasil Penelitian dan Pengabdian Masyarakat 2016, Politeknik Negeri Jember, Jember, 2016.

[20] Luis Federico Martinez, Murat Omer Balaban, Quality Enhancement of Coffee Beans by Acid and Enzyme Treatment, in: U. Patent (Ed.), US, 2009.

[21] Sinar Tani, Kopi luwak probiotik temuan BPTP Bali, in: Tabloid Sinar Tani, Sinar Tani, Jakarta, 2010.
[22] Mulyana Hadipernata, Rudy Tjahjohutomo, Iceu Agustinisari, Eka Rahayu, Teknologi proses dan keamanan pangan kopi luwak, in: Seminar Nasional Teknologi Inovatif Pascapanen Pertanian III, Bogor, 2011.

[23] Mareike Kraatz, Lactobacilli and other lactic acidrelated bacteria in the mucosal proximal gastrointestinal tract of pigs: a review of ecology for two derivative approaches for isolation of novel species, Current Research, Technology and Education Topics in Applied Microbiology and Microbial Biotechnology, 1, (2010) 674-686

[24] Stephanie Chan, Emmanuel Garcia, Comparative Physicochemical Analyses of Regular and Civet Coffee, The Manila Journal of Science, 7, 1, (2011) 1923

[25] Sony Suhandono, Heri Setiadi, Tati Kristianti, Ali Budhi Kusuma, Andini Warih Wedaringtyas, Demi Tristan Djajadi, I Nyoman Pugeg Aryantha, Diversity of culturable Bacterial in various parts of luwak's (Paradoxurus hermaprodithus javanica) gastrointestinal tract, Microbiology Indonesia, 10, 2, (2016) 65-70

[26] Sri Laksmi Dewi, Isolasi Bakteri Xilanolitik Dan Selulolitik Dari Feses Luwak, Departemen Biologi, Institut Pertanian Bogor, Bogor

[27] Pandudamai Insani Taufiq, Fermentasi Kopi Menggunakan Bakteri Xilanolitik dari Luwak, Departemen Ilmu dan Teknologi Pangan, Institut Pertanian Bogor, Bogor

[28] Siti Zahiroh, Fermentasi Biji Kopi Menggunakan Bakteri Selulolitik, Xilanolitik dan Proteolitik Asal Luwak, Departemen Teknologi Agroindustru, Institut Pertanian Bogor, Bogor

[29] Hazirur Rohman, Produksi Kopi Secara Enzimatis Menggunakan Bakteri Proteolitik dan Kombinasi Bakteri Selulolitik dan Xilanolitik Dari Luwak, Departemen Teknologi Agroindustri, Institut Pertanian Bogor, Bogor

[30] Nur Richana, Produksi dan Prospek Enzim Xilanase dalam Pengembangan Bioindustri di Indonesia, Buletin AgroBio, 5, 1, (2002) 29-36

[31] Maggy Thenawidjaja Suhartono, Enzim dan bioteknologi, PAU Bioteknologi, Institut Pertanian Bogor, Bogor, 1989.

[32] Prabuddha Bansal, Mélanie Hall, Matthew J. Realff, Jay H. Lee, Andreas S. Bommarius, Modeling cellulase kinetics on lignocellulosic substrates, Biotechnology Advances, 27, 6, (2009) 833-848 https://doi.org/10.1016/j.biotechadv.2009.06.005

[33] Kementerian Pertanian, Peraturan Menteri Pertanian Republik Indonesia Nomor 37/Permentan/KB.120/6/2015 Tentang Cara Produksi Kopi Luwak Melalui Pemeliharaan Luwak yang Memenuhi Prinsip Kesejahteraan Hewan, in: K. Pertanian (Ed.) No. 37/Permentan/KB.120/6/2015, Kementerian Pertanian, Jakarta, 2015.

[34] Israyanti, Perbandingan Karakteristik Kimia Kopi Luwak dan Kopi Biasa Jenis Kopi Arabika (Cafeea arabica. L) dan Robusta (Cafeea canephora. L), 
Program Studi Teknologi Pertanian, Universitas Hasanuddin, Makassar

[35] I. Filya, G. Ashbell, Y. Hen, Z. G. Weinberg, The effect of bacterial inoculants on the fermentation and aerobic stability of whole crop wheat silage, Animal Feed Science and Technology, 88, 1, (2000) 39-46 https://doi.org/10.1016/S0377-8401(00)00214-5

[36] Michael J. Jr. Pelczar, E.C.S. Chan, Dasar-Dasar Mikrobiologi, UI Press, Jakarta, 2005.

[37] Badan Standardisasi Nasional, Biji Kopi, in: B.S. Nasional (Ed.) SNI 2907:2008, Badan Standardisasi Nasional, Jakarta, 2008.

[38] Naeli Farhaty, Muchtaridi Muchtaridi, Tinjauan Kimia dan Aspek Farmakologi Senyawa Asam Klorogenat Pada Biji Kopi : Review, Farmaka, 14, 1, (2016) 214-227

[39] H.D. Belitz, W. Grosch, P. Schieberle, Lehrbuch der Lebensmittelchemie, Springer Berlin Heidelberg, 2007.

[40] Kenneth Todar, Todar's Online Textbook of Bacteriology, in, www.textbookofbacteriology.net, 2018.

[41] Ana Farida, Evi Ristanti R, Andri Cahyo Kumoro, Penurunan Kadar Kafein dan Asam Total Pada Biji Kopi Robusta Menggunakan Teknologi Fermentasi Anaerob Fakultatif dengan Mikroba Nopkor MZ-15, Jurnal Teknologi Kimia dan Industri, 2, 3, (2013) 70-75

[42] Adriana Farah, Carmen Marino Donangelo, Phenolic compounds in coffee, Brazilian Journal of Plant Physiology, 18, (2006) 23-36 http://dx.doi.org/10.1590/S1677$\underline{04202006000100003}$

[43] Adriana Dillenburg Meinhart, Lucas Caldeirão, Fernanda Mateus Damin, José Teixeira Filho, Helena Teixeira Godoy, Analysis of chlorogenic acids isomers and caffeic acid in 89 herbal infusions (tea), Journal of Food Composition and Analysis, 73, (2018) 76-82 https://doi.org/10.1016/j.jfca.2018.08.001

[44]Rachid Bel-Rhlid, Dinesh Thapa, Karin Kraehenbuehl, Carl Erik Hansen, Lutz Fischer, Biotransformation of caffeoyl quinic acids from green coffee extracts by Lactobacillus johnsonii NCC 533, AMB Express, 3, (2013) 28-28 http://dx.doi.org/10.1186/2191-0855-3-28

[45] Yi-Fang Chu, Coffee: Emerging Health Effects and Disease Prevention, Wiley, 2012.

[46] Meenakshi Arya, L. Jagan Mohan Rao, An Impression of Coffee Carbohydrates, Critical Reviews in Food Science and Nutrition, 47, 1, (2007) 51-67 http://dx.doi.org/10.1080/10408390600550315

[47] Dietrich Fengel, Gerd Wegener, Wood: chemistry, ultrastructure, reactions, De Gruyter, 2011.

[48] Anuj K. Chandel, G. Chandrasekhar, Messias Borges Silva, Silvio Silvério da Silva, The realm of cellulases in biorefinery development, Critical Reviews in Biotechnology, 32, 3, (2012) 187-202 http://dx.doi.org/10.3109/07388551.2011.595385

[49] Fatria Isrami, Agustina L. N. Aminin, Aktivitas Selulase dan Xilanase dari Komplek Enzim
Lignoselulolitik Termostabil Hasil Penguraian Batang Pisang, Jurnal Kimia Sains dan Aplikasi, 17, 1, (2014) 17-22 https://doi.org/10.14710/jksa.17.1.17-22

[50] Raj Kumar, Sompal Singh, Om V. Singh, Bioconversion of lignocellulosic biomass: biochemical and molecular perspectives, Journal of Industrial Microbiology \& Biotechnology, 35, 5, (2008) 377-391 http://doi.org/10.1007/s10295-008-0327-8

[51] A. T. W. M. Hendriks, G. Zeeman, Pretreatments to enhance the digestibility of lignocellulosic biomass, Bioresource Technology, 100, 1, (2009) 10-18 https://doi.org/10.1016/j.biortech.2008.05.027

[52] Deepa Deswal, Yogender Pal Khasa, Ramesh Chander Kuhad, Optimization of cellulase production by a brown rot fungus Fomitopsis sp. RCK2010 under solid state fermentation, Bioresource Technology, 102, 10, (2011) 6065-6072 https://doi.org/10.1016/j.biortech.2011.03.032

[53] Ramesh Chander Kuhad, Rishi Gupta, Ajay Singh, Microbial Cellulases and Their Industrial Applications, Enzyme Research, 2011, (2011) 10 http://doi.org/10.4061/2011/280696

[54] Anton Susilo, Produksi Kopi Luwak Sintesis Secara Enzimatis menggunakan Bakteri Xilanolitik dan Kombinasi dengan Bakteri Proteolitik dan Selulolitik, Departemen Teknologi Agroindustri, Institut Pertanian Bogor, Bogor

[55] Li Wan Yoon, Teck Nam Ang, Gek Cheng Ngoh, Adeline Seak May Chua, Fungal solid-state fermentation and various methods of enhancement in cellulase production, Biomass and Bioenergy, 67, (2014) https://doi.org/10.1016/j.biombioe.2014.05.013

[56] Y. H. Percival Zhang, Michael E. Himmel, Jonathan R. Mielenz, Outlook for cellulase improvement: Screening and selection strategies, Biotechnology Advances, 24, 5, (2006) 452-481 https://doi.org/10.1016/j.biotechadv.2006.03.003

[57] M. Dashtban, H. Schraft, W. Qin, Fungal bioconversion of lignocellulosic residues; opportunities \& perspectives, International Journal of Biological Sciences, 5, 6, (2009) 578-595 http://doi.org/10.7150/ijbs.5.578

[58] Paul Held, Enzymatic digestion of polysaccharides part II: Optimization of polymer digestion and glucose production in microplates," Biofuel Res., hal. 5, 2012., in: Applications notes: Biofeul Research, BioTek, 2012.

[59] S. Subramaniyan, P. Prema, Biotechnology of Microbial Xylanases: Enzymology, Molecular Biology, and Application, Critical Reviews in Biotechnology, 22, 1, (2002) 33-64 10.1080/07388550290789450

[60]Michael P. Coughlan, Geoffrey P. Hazlewood, Hemicellulose and hemicellulases, Portland Press, 1993.

[61] Kunamneni Adinarayana, Poluri Ellaiah, Davuluri Siva Prasad, Purification and partial characterization of thermostable serine alkaline protease from a newly isolated Bacillus subtilis PE-11, AAPS 
PharmSciTech, 4, 4, (2003) E56-E56 http://doi.org/10.1208/pt040456

[62] Peter James Baker, Keiji Numata, Polymerization of Peptide Polymers for Biomaterial Applications, in: F. Yllmaz (Ed.) Polymer Science, IntechOpen, 2013.

[63] Murna Muzaifa, Dian Hasni, Anshar Patria, Febriani, Amhar Abubakar, Sensory and Microbial Characteristics of Civet Coffee, International Journal on Advanced Science, Engineering and Information Technology (IJASEIT), 8, 1, (2018) 165-171

[64] L. M. Cintas, M. P. Casaus, C. Herranz, I. F. Nes, P. E. Hernández, Review: Bacteriocins of Lactic Acid Bacteria, Food Science and Technology International, 7 , 4, (2001) 281-305 http://doi.org/10.1106/r8dep6hu-clxp-5ryt

[65] Mulyana Hadipernata, Sigit Nugraha, Identifikasi Fisik, Kimia dan Mikrobiologi Biji Kopi Luwak sebagai Dasar Acuan Teknologi Proses Kopi Luwak Artificial, in: Seminar Insentif Riset SINas (INSINas 2012), Bandung, 2012.

[66] S. Radha, A. Sridevi, R. Himakiran Babu, V. J. Nithya, N. B. L. Prasad, G. Narasimha, Medium Optimization for Acid protease production from Aspergillus sps under Solid state fermentation and mathematical modelling of protease activity, Journal of Microbiology and Biotechnology Research, 2, 1, (2012) 6-16

[67] Grażyna Budryn, Ewa Nebesny, Anna Podsędek, Dorota Żyżelewicz, Małgorzata Materska, Stefan Jankowski, Bogdan Janda, Effect of different extraction methods on the recovery of chlorogenic acids, caffeine and Maillard reaction products in coffee beans, European Food Research and Technology, 228, 6, (2009) 913-922 http://doi.org/10.1007/s00217-008-1004-X

[68] Dennis D. Miller, Food Chemistry: A Laboratory Manual, Wiley, 1998.

[69]J.R. Vercellotti, A.J. St Angelo, A.M. Spanier, Lipid oxidation in foods: An overview, ACS Symposium series-American Chemical Society (USA), (1992)

[70] Ivon Flament, Yvonne Bessière-Thomas, Coffee flavor chemistry, John Wiley \& Sons, 2002. 